\title{
Immune Response in Cattle Vaccinated against Rabies
}

\author{
Alexandre Nunes de Oliveira/ ${ }^{+}$, Márcia Cristina Ribeiro Andrade*, \\ Marlon Vicente da Silva**, Wlamir Corrêa de Moura***, \\ Ellen Cortez Contreiras $* * * *$
}

Centro de Controle de Zoonoses Paulo Dacorso Filho, Largo do Bodegão s/nº, 23550-050 Rio de Janeiro, RJ, Brasil *Centro de Criação de Animais de Laboratório, Departamento de Primatologia, Fundação Oswaldo Cruz, Rio de Janeiro, RJ, Brasil **Laboratório de Raiva e Sorologia, Instituto Municipal de Medicina Veterinária Jorge Vaitsman, Rio de Janeiro, RJ, Brasil ***Laboratório de Raiva, Departamento de Imunologia, Instituto Nacional de Controle de Qualidade em Saúde, Fundação Oswaldo Cruz ****Instituto de Veterinária, Departamento de

Microbiologia e Imunologia, Universidade Federal Rural do Rio de Janeiro, Seropédica, RJ, Brasil

In order to determine the best type of rabies vaccine to use as a booster, 78 serological samples from singly vaccinated cattle were analyzed by counterimmunoelectrophoresis technique. The animals were divided into several groups, received the first vaccine dose with modified live virus vaccine (ERA strain) and were revaccinated with inactivated virus or modified live virus vaccines. Boosters were given at 2, 4, 8, 12 and 16 weeks following first vaccination. Results showed high titres in the cases of booster with inactivated vaccine. In all cases, however, detectable antibody titres declined quickly.

Key words: rabies - cattle - vaccination - booster - serology

Rabies has been recorded since ancient times. At present, the disease still causes remarkable economic damage through loss of animals destined for production, mainly in Latin America. In Brazil, bovine and equine herds are severely affected by the disease. The resulting loss is a consequence of the failure of herd owners to vaccinate their animals appropriately. In fact, the only effective means of rabies control in herbivores is routine vaccination and control of the vampire bat (Desmodus rotundus) populations.

The countless types of commercially available vaccines make it difficult to determine clear procedures for effective immunization of the animals. Handling and storage of some types of vaccines require special care. Many herd owners vaccinate their animals periodically, but use different types of vaccine in subsequent vaccinations. Some of them complain of loss of animals during long postvaccinal periods despite following rigorous vaccination schedules. Such loss can be attributed to inadequate use of the vaccines, and to failure of the vaccine to adequately immunize the animals or to protect them against possible antigenic variations of the rabies viruses present in the bat populations.

\footnotetext{
${ }^{+}$Corresponding author. Fax: +55-21-395.2190. E-mail: ande@provide.psi.br

Received 17 June 1999

Accepted 26 October 1999
}

The correct use of the different types of commercially available rabies vaccines is often ignored or neglected. Sometimes vaccinations are only undertaken after the first animals are lost and thus individual animals which already incubate the disease may die even after vaccination.

The effect of modified live virus (MLV) booster is still unknown in Brazilian livestock. Theoretically, the live virus used as a second vaccination could be neutralized by already circulating antibodies produced in response to the primary vaccination. In this case, the inoculated live virus could be inactivated and come to act as a booster of inactivated virus (IV) vaccine, although with much less potency than those of the inactivated vaccines with adjuvant. Alternatively, there are indications that some MLV vaccines are not inducing adequate titres of neutralizing antibodies against rabies virus, mainly in singly vaccinated animals (Ciuchini et al. 1981). These vaccines are probably more effective in inducing cellular immunity than humoral immunity.

A better understanding of the effects of the boosters and the immunological memory mechanisms in cattle is thus necessary, especially to enable us to assist professionals in a correct approach to the question of rabies vaccination. The purpose of this paper is to define the most adequate type of vaccine for use in booster schedules against rabies in cattle and to verify the best period for booster of singly vaccinated heifers with MLV by analyzing circulating neutralizing antibody titres. 


\section{MATERIALS AND METHODS}

Animals - Seventy-eight half-breed zebu/ european cattle (Bos taurus) destined for slaughter, between six months and one year of age, were evaluated in this study. These cattle had no history of previous rabies vaccination so as to minimize the possible interference of maternal antibodies (Tollis 1989).

All regular management practices of the farm were maintained unchanged during the period of the trial, except with regard to rabies vaccination. In the week preceding and following vaccination no chemotherapeutic products were used.

Vaccines - Two distinct types of commercially available rabies vaccines were used: MLV vaccine from the Evelyn-Rockitinicki-Abelseth (ERA) strain, and IV vaccine produced with fixed Pasteur virus in cell culture. The vaccines were obtained directly from the producers. The infecting titre of the MLV vaccine was $10^{-3,75}$ and of the IV vaccine was $10^{-5,58}$ (Habel 1976).

Vaccination - Vaccines were kept refrigerated and used within the expiration date. Vaccination was carried out rigorously observing the recommedations of the manufacturers: the MLV vaccine was used within $1 \mathrm{~h}$ of reconstitution and kept refrigerated; the IV vaccine was administered following the same criteria used for the MLV vaccine. Each animal received $2 \mathrm{ml}$ of MLV or IV vaccines by intramuscular route (gluteus muscle).

The animals were iron marked at day 0 using a maximum of two digits, forming a total of 13 groups of six animals each, numbered $0,1,2,3.1$, 3.2, 4.1, 4.2, 5.1, 5.2, 6.1, 6.2, 7.1 and 7.2.

Control groups - Animals were divided into three groups $(0,1,2)$ with six animals each. Group 0 was not vaccinated. Group 1 received a single dose of IV vaccine, and group 2 received one dose of MLV vaccine during the whole period of the experiment.

Test vaccine groups - Animals were divided into ten groups of six animals each. All of them received a first dose of MLV vaccine. Five groups received a booster of IV vaccine and five groups received MLV vaccine. Each of the groups received the booster at a different time after the first vaccination starting at the 2 nd week after primovaccination until the 16th week. Groups 3.1 and 3.2 received boosters in the 2 nd week; groups 4.1 and 4.2 received boosters in the 4 th week; groups 5.1 and 5.2 received boosters in the 8 th week; groups 6.1 and 6.2 received boosters in the 12th week; and groups 7.1 and 7.2 received boosters in the 16 th week.

Collection of samples - Serological samples were collected at $0,2,4,6,8,12,16,20,28$ and 32 weeks following the first vaccination. A blood sample of approximately $10 \mathrm{ml}$ was collected from the jugular vein of each animal. Samples were kept refrigerated for approximately $12 \mathrm{~h}$ to allow coagulation. The sera obtained were purified by centrifugation, the complement inactivated for $30 \mathrm{~min}$ at $56^{\circ} \mathrm{C}$ and then frozen at $-20^{\circ} \mathrm{C}$ until tested.

Serological study - Rabies titres were analyzed by counterimmunoelectrophoresis (CIE) (Diaz \& Myers 1980) with modifications recommended by Moura (1993). Two lots of antigen (003/94 and 004/94) were used, both of them prepared by passage of CVS-31 in suckling mice. Titres of the antigen were determined in comparison with standard serum using an optimal dilution of 1:8 and 1:40, respectively. A pool of sera from rabbits hyperimmunized against rabies was used as positive control (lot 002/92), at standard dilution of 1:30 for a titre of 1.024 by CIE technique.

\section{RESULTS}

Control groups - None of the animals in group 0 (naive) tested positive for rabies antibodies during the course of the experiment. Group 1 obtained a maximum titre of 2.0. Only one animal developed a titre in the 2 nd week post-vaccination and two animals were seropositive at the 4th week. From the 6th week on all animals were seronegative by CIE. Only one animal of group 2 developed a titre $(=2.0)$ in the 2 nd and 4 th weeks. No animals developed rabies antibodies from the 6th week after vaccination (Table I).

\section{Revaccinated groups}

$2 n d$ week - In the group receiving a booster dose with IV vaccine (group 3.1) one animal developed a titre $(=4.0)$ at the moment of booster. Two weeks after the booster all animals developed a titre of 2.0. On the other hand, already in the 4th week following the booster, only one animal developed a measurable titre. From the 10th week no animal showed seropositivity. In the group that received a booster dose with the MLV vaccine (group 3.2) there were no detectable titres during the whole course of the experiment (Table II).

4th week - One hundred percent of the animals that received IV vaccine as a booster at the 4th week (group 4.1) developed a titre in the 2 nd week following the booster. Overall, $33 \%$ of the animals developed detectable titres. Only one animal developed a titre between the 8th and 16th week after the booster dose (Table III). The group that received the MLV vaccine booster at the 4th week did not develop detectable titres.

8 th week - Only one animal of the group that received IV vaccine (group 5.1) did not develop a titre in the 4th week after the booster. From the 12 th week on all animals were seronegative. In the group that received MLV vaccine booster at the 8th week (group 5.2) only one animal devel- 
TABLE I

Results of serology (antibody detection) obtained by counterimmunoelectrophoresis in the control groups maximum and minimum titres and ratio positives/total

\begin{tabular}{|c|c|c|c|c|c|c|}
\hline \multirow[b]{2}{*}{ Week } & \multicolumn{2}{|c|}{ Group 0} & \multicolumn{2}{|c|}{ Group 1} & \multicolumn{2}{|c|}{ Group 2} \\
\hline & $\begin{array}{c}\mathrm{CIE}^{a} \\
b\end{array}$ & Pos/Total & $\begin{array}{c}\mathrm{CIE}^{a} \\
b\end{array}$ & Pos/Total & $\begin{array}{c}\mathrm{CIE}^{a} \\
b\end{array}$ & Pos/Total \\
\hline 0 & - & $0 / 6$ & - & $0 / 6$ & - & $0 / 6$ \\
\hline 2 & - & $0 / 6$ & 2 & $1 / 6$ & 2 & $1 / 6$ \\
\hline 4 & - & $0 / 6$ & 2 & $2 / 6$ & 2 & $1 / 6$ \\
\hline 6 & - & $0 / 6$ & - & $0 / 6$ & - & $0 / 6$ \\
\hline 8 & - & $0 / 6$ & - & $0 / 6$ & - & $0 / 6$ \\
\hline 12 & - & $0 / 4$ & - & $0 / 6$ & - & $0 / 6$ \\
\hline 16 & - & $0 / 4$ & - & $0 / 6$ & - & $0 / 6$ \\
\hline 20 & - & $0 / 6$ & - & $0 / 6$ & - & $0 / 6$ \\
\hline 28 & - & $0 / 6$ & - & $0 / 4$ & - & $0 / 6$ \\
\hline 32 & - & $0 / 3$ & - & $0 / 6$ & - & $0 / 3$ \\
\hline
\end{tabular}

$a$ : titre expressed as inverse of sera dilutions; $b$ : variation of titres.

TABLE II

Results of serology (antibody detection) obtained by counterimmunoelectrophoresis in the groups revaccinated in the 2 nd week with live virus or inactivated virus vaccine - maximum and minimum titres and ratio positives/total

\begin{tabular}{lcclll}
\hline & \multicolumn{2}{c}{ Group 3.1 } & & \multicolumn{2}{c}{ Group 3.2 } \\
\cline { 2 - 3 } \cline { 5 - 6 } Week & CIE $^{a}$ & Pos/Total & & CIE $^{a}$ & Pos/Total \\
& $b$ & & & & \\
\hline 0 & - & $0 / 6$ & & - & $0 / 6$ \\
$2^{c}$ & 4 & $1 / 6$ & & - & $0 / 6$ \\
4 & 2 & $6 / 6^{d}$ & & - & $0 / 6$ \\
6 & 2 & $1 / 6$ & & - & $0 / 6$ \\
8 & 2 & $1 / 6$ & & - & $0 / 5$ \\
12 & - & $0 / 6$ & & - & $0 / 6$ \\
16 & - & $0 / 6$ & & - & $0 / 6$ \\
20 & - & $0 / 4$ & & - & $0 / 6$ \\
28 & - & $0 / 4$ & & - & $0 / 6$ \\
32 & - & $0 / 2$ & & - & $0 / 3$ \\
\hline
\end{tabular}

$a$ : titre expressed as inverse of sera dilutions; $b$ : variation of titres; $c$ : week of booster; $d: \mathrm{x}^{2}=8.57$ [significant result, $\left.\mathrm{x}^{2}>6.635(\mathrm{p}=0.01)\right]$.

oped titre of 2.0, detected in the 4th week after the booster (Table IV).

12th week - In the group receiving a booster dose with IV vaccine (group 6.1), all animals had detectable titres by the 4 th week after the booster. In the 8th week, however, only one animal showed a titre. In the group that received MLV vaccine booster at the 12th week (group 6.2), none of the animals developed a detectable titre (Table V).

16th week - In both groups, titres were detected in the 4th week after the booster; with $83 \%$ of the animals in group 7.1 responding compared to $17 \%$ in group 7.2 (Table VI).

Statistical analyses - The results of the analyses of the sera collected from the groups which

\section{TABLE III}

Results of serology (antibody detection) obtained by counterimmunoelectrophoresis in the groups revaccinated in the 4 th week with live virus or inactivated virus vaccine - maximum and minimum titres and ratio positives/total

\begin{tabular}{lcclll}
\hline & \multicolumn{2}{c}{ Group 4.1 } & & \multicolumn{2}{c}{ Group 4.2 } \\
\cline { 2 - 3 } \cline { 5 - 6 } Week & $\mathrm{CIE}^{a}$ & Pos/Total & & $\mathrm{CIE}^{a}$ & Pos/Total \\
& $b$ & & & $b$ & \\
\hline 0 & - & $0 / 6$ & & - & $0 / 6$ \\
2 & - & $0 / 6$ & & - & $0 / 6$ \\
$4^{c}$ & - & $0 / 6$ & & - & $0 / 6$ \\
6 & $2-8$ & $6 / 6^{d}$ & & - & $0 / 6$ \\
8 & $2-4$ & $2 / 6$ & & - & $0 / 6$ \\
12 & 4 & $1 / 6$ & & - & $0 / 6$ \\
16 & 2 & $1 / 6$ & & - & $0 / 6$ \\
20 & 2 & $1 / 6$ & & - & $0 / 6$ \\
28 & - & $0 / 6$ & & - & $0 / 4$ \\
32 & - & $0 / 6$ & & - & $0 / 5$ \\
\hline
\end{tabular}

$a$ : titre expressed as inverse of sera dilutions; $b$ : variation of titres; $c$ : week of booster; $d: \mathrm{x}^{2}=12$ [significant result, $\left.\mathrm{x}^{2}>6.635(\mathrm{p}=0.01)\right]$.

were given a booster dose with respect to the presence or not of detectable antibodies obtained by CIE were statistically analyzed using the chi-square test, $\mathrm{p}=0.01$. All groups revaccinated with IV vaccine demonstrated significant results when compared with the control group vaccinated with MLV vaccine during the same period after the first vaccination. The groups revaccinated with MLV vaccine did not demonstrate significant results. The results are expressed at the end of each table.

\section{DISCUSSION}

Dogs are responsible for the vast majority of human rabies deaths as they are the main transmitters of urban rabies. Vampire bats are considered 


\section{TABLE IV}

Results of serology (antibody detection) obtained by counterimmunoelectrophoresis in the groups revaccinated in the 8th week with live virus or inactivated virus vaccine - maximum and minimum titres and ratio positives/total

\begin{tabular}{lcclll}
\hline & \multicolumn{2}{c}{ Group 5.1 } & & \multicolumn{2}{c}{ Group 5.2 } \\
\cline { 2 - 3 } \cline { 5 - 6 } Week & $\mathrm{CIE}^{a}$ & Pos/Total & & $\mathrm{CIE}^{a}$ & Pos/Total \\
& $b$ & & & $b$ & \\
\hline 0 & - & $0 / 6$ & & - & $0 / 6$ \\
2 & - & $0 / 6$ & & - & $0 / 6$ \\
4 & - & $0 / 6$ & & - & $0 / 6$ \\
6 & - & $0 / 6$ & & - & $0 / 6$ \\
$8^{c}$ & - & $0 / 6$ & & - & $0 / 6$ \\
12 & $2-4$ & $5 / 6$ & & 2 & $1 / 5$ \\
16 & 2 & $3 / 6$ & & - & $0 / 6$ \\
20 & - & $0 / 6$ & & - & $0 / 5$ \\
28 & - & $0 / 6$ & & - & $0 / 6$ \\
32 & - & $0 / 6$ & & - & $0 / 5$ \\
\hline
\end{tabular}

$a$ : titre expressed as inverse of sera dilutions; $b$ : variation of titres; $c$ : week of booster; $d: \mathrm{x}^{2}=8.57$ [significant result, $\left.\mathrm{x}^{2}>6.635(\mathrm{p}=0.01)\right]$.

\section{TABLE V}

Results of serology (antibody detection) obtained by counterimmunoelectrophoresis in the groups revaccinated in the 12th week with live virus or inactivated virus vaccine - maximum and minimum titres and ratio positives/total

\begin{tabular}{lcclll}
\hline & \multicolumn{2}{c}{ Group 6.1 } & & \multicolumn{2}{c}{ Group 6.2 } \\
\cline { 2 - 3 } \cline { 5 - 6 } Week & $\mathrm{CIE}^{a}$ & Pos/Total & & $\mathrm{CIE}^{a}$ & Pos/Total \\
& $b$ & & & $b$ & \\
\hline 0 & - & $0 / 6$ & & - & $0 / 6$ \\
2 & - & $0 / 6$ & & - & $0 / 6$ \\
4 & - & $0 / 6$ & & - & $0 / 6$ \\
6 & - & $0 / 6$ & & - & $0 / 6$ \\
8 & - & $0 / 6$ & & - & $0 / 6$ \\
$12^{c}$ & - & $0 / 6$ & & - & $0 / 6$ \\
16 & $2-4$ & $6 / 6$ & & - & $0 / 6$ \\
20 & 2 & $1 / 6$ & & - & $0 / 5$ \\
28 & - & $0 / 6$ & & - & $0 / 6$ \\
32 & - & $0 / 6$ & & - & $0 / 5$ \\
\hline
\end{tabular}

$a$ : titre expressed as inverse of sera dilutions; $b$ : variation of titres; $c$ : week of booster; $d: \mathrm{x}^{2}=8.57$ [significant result, $\left.\mathrm{x}^{2}>6.635(\mathrm{p}=0.01)\right]$.

the main transmitters of rabies in the wild (Meslin et al. 1994). As to the number of cases of human rabies, about $15 \%$ of deaths are attributable to bats. This problem is the result of large pieces of land used for monocultures, resulting in a reduced number of animals and lack of food for the vampire bats or due to regions with constant deforestation (Schneider 1990). The migration of the human population from rural to urban areas contributes signifi-

\section{TABLE VI}

Results of serology (antibody detection) obtained by counterimmunoelectrophoresis in the groups revaccinated in the 16th week with live virus or inactivated virus vaccine - maximum and minimum titres and ratio positives/total

\begin{tabular}{lcclll}
\hline & \multicolumn{2}{c}{ Group 7.1 } & & \multicolumn{2}{c}{ Group 7.2 } \\
\cline { 2 - 3 } \cline { 5 - 6 } Week & $\mathrm{CIE}^{a}$ & Pos/Total & & $\mathrm{CIE}^{a}$ & Pos/Total \\
& $b$ & & & $b$ & \\
\hline 0 & - & $0 / 6$ & & - & $0 / 6$ \\
2 & - & $0 / 6$ & & - & $0 / 6$ \\
4 & - & $0 / 6$ & & - & $0 / 6$ \\
6 & - & $0 / 6$ & & - & $0 / 6$ \\
8 & - & $0 / 6$ & & - & $0 / 6$ \\
12 & - & $0 / 6$ & & - & $0 / 6$ \\
$16^{c}$ & - & $0 / 6$ & & - & $0 / 6$ \\
20 & 2 & $5 / 6$ & & 2 & $1 / 6$ \\
28 & - & $0 / 6$ & & - & $0 / 6$ \\
32 & - & $0 / 4$ & & - & $0 / 6$ \\
\hline
\end{tabular}

$a$ : titre expressed as inverse of sera dilutions; $b$ : variation of titres; $c$ : week of booster; $d: \mathrm{x}^{2}=12$ [significant result, $\left.\mathrm{x}^{2}>6.635(\mathrm{p}=0.01)\right]$.

cantly to the creation of artificial shelters (Gambeta et al. 1979). This was confirmed in the State of São Paulo, Brazil, where of the 113 wildlife refuges of D. rotundus, only $28(24.8 \%)$ were natural and 85 (75.2\%) were artificial (Tadei et al. 1991).

Rabies vaccination in animals is normally undertaken pre-exposure. This protective measure aims to interrupt the transmission cycle in wildlife, interrupt the cycle between domestic and wild animals, and thus prevent the disease in man (Tollis 1989, Baer 1991). The detection of specific serical neutralizing antibodies is evidence of immune response of the vaccinated animal (Atanasiu et al. 1968).

Commercially available rabies vaccines for veterinary use can be prepared with MLV or with IV virus strains. The immune response to MLV vaccine depends on the replication of the virus in the tissues of the animal, producing a specific response to the modified rabies virus infection. It is likely that the virus of the MLV vaccine continues to replicate in the tissues of the individual until antibodies develop in sufficient number to neutralize or completely inactivate the virus (Atanasiu et al. 1968). The quantity of viral particles present in the IV vaccine is higher than that in the MLV vaccine. The immunization potency of the latter is related to the replication of the virus in the muscular tissue, and therefore requires entire and viable virions. This may explain the fact that the additional dose of MLV vaccine did not induce adequate levels of rabies antibodies during the tested period.

The immunity produced by IV vaccine is basically associated with the quantity of antigen in the vaccine. In this case, no replication takes place 
and immunity is established after the first vaccination (Atanasiu et al. 1976). The control group vaccinated with IV vaccine was included to preclude any doubt about the kind of response, primary or secondary, after the booster. The response to the booster dose with the IV vaccine was overwhelmingly of the secondary type. These animals demonstrated a considerable rise in rabies titres reaching much higher levels than found in the animals vaccinated with a single dose of IV vaccine (control group), which showed characteristics of primary response. The secondary response was not so well characterized in the animals which were given a booster dose with the MLV vaccine where the highest titre $(=2.0)$ was found in the group boosted eight weeks after the first dose.

The defense mechanisms against the virus include nonspecific and specific mechanisms. Probably the most important among the nonspecific mechanisms against virus infection is the phenomenon of interference where interferons are produced immediately after viral invasion (Tizard 1985, Fenner 1993, Abbas et al. 1995). In the studies of Ito (1988), antigen consumption was not observed after the booster with IV vaccine. Likewise, consumption of rabies antigen and blocking of epitopes by antibodies that develop after the first vaccination was not observed in this study when using a booster dose of IV vaccine. The low response to the booster with MLV was possibly caused by the phenomenon of interference related to the restricted infection that occurred after the first vaccination or to neutralization of the virus, inhibiting absorbtion or penetration of a great number of particles into the cells.

The relative ease with which the antibodies can be measured, albeit not very accurately, is fundamental to evaluating the efficiency of antirabies vaccines (Turner 1985). The CIE technique, for example, evaluates neutralizing antibodies directed against the glycoprotein of the rabies virus (Diaz \& Myers 1980). Albas et al. (1992) considered CIE sufficiently sensitive to be used in the evaluation of the immune response of bovines to rabies vaccine, only needing to be adequately correlated with the standard neutralization test in mice (Atanasiu 1976, Diaz \& Myers 1984). This technique was developed for the detection of rabies antibodies and detects immunoglobulin $\mathrm{G}$ (IgG). By measuring antibodies directed against the glycoprotein in the viral surface, CIE detects the neutralizing potential of the sera studied (Diaz \& Myers 1981).

In the rabies virus neutralization test IgM and $\mathrm{IgG}$ are titrated jointly. As a result, this test is influenced by the concentration of IgM, even though levels are not highly effective under natural conditions. The quality of the rabies vaccine can delay the primary response due to aging of the antigen.
Rabies vaccines for veterinary use containing large quantities of impurities and adjuvants or inadequate immunogen may also delay this primary response. The different characteristics of the immunoglobulins suggest new theories of immunoregulation which will lead to new studies to determine their role in the resistance to rabies infection, as well as to develop more adequate techniques for their identification.

Oliveira et al. (1994) used CIE to analyze 118 samples from bovines vaccinated against rabies, collected between 1 and 12 months following vaccination. Only 16 samples (13.5\%) showed antibody titres equal to or higher than 2 . In the present study, the efficacy of CIE in the detection of rabies antibodies in bovines has been demonstrated in the samples collected after the booster, mainly after booster doses with IV vaccine. The peak of antibody titres in animals after the first vaccination with MLV vaccine was verified in the 2 nd week after vaccination and declined subsequently as described by Ciuchini et al. (1981).

Montaño et al. (1983), working with bovines, verified that $88.2 \%$ of the animals which received a booster dose of Fuenzalida and Palacios modified vaccine one year after the first vaccination with ERA vaccine presented a titre of $\geq 25$ in the neutralization test in mice in the 4th month after the booster. The sera of the animals which contained antibodies were more effective in protecting mice using fixed virus than when using a street rabies virus. Atanasiu et al. (1976) working with MLV vaccine produced in pig kidney cells and with IV vaccine prepared in suckling mice brain tissue, concluded that additional doses of these vaccines in bovines, 30 days after the first vaccination, increased the titres of neutralizing rabies antibodies considerably within a period of eight days. The neutralization test in mice showed titres greater than 125. This procedure, however, does not seem to influence the persistence of the antibodies.

The results presented indicate that a single dose of any of the tested vaccines does not induce detectable levels of antibodies in the majority of the animals after the first vaccination. Increase of antibody titres was only observed in some animals two and/or four weeks following vaccination. The maintenance of antibody titres was critical in the major part of the groups. The groups which best maintained the titres were those groups receiving a booster of IV vaccine after four to eight weeks. The fastest decline of titres occurred in the groups revaccinated in the $2 n d$ week and after the 12th weeks. The decline of titres in the 12th week may have occurred due to a decrease in the number of memory cells.

In this experiment we observed that one dose of MLV vaccine was able to induce a memory immune response against the rabies virus. The re- 
sponses to the booster doses were considered secondary responses. The most efficient boosters, evaluated by CIE, were those using IV vaccine, mainly in groups 4.1 and 5.1 (booster in the 4th and 8th weeks, respectively).

The cellular immune response induced by the tested vaccines was not evaluated. This response may be important for the resistance to rabies infection due to its role in overcoming established infection and is likely induced by MLV vaccine which produces modified infection.

Besides vaccination, the reduction of bat populations is an important factor in the control of rabies. The increasing creation of artificial shelters and the abundant food sources available to $D$. rotundus (Gambeta et al. 1979, Greenhall 1988, Tadei et al. 1991) are all responsible for the rapid growth in vampire bat populations, a problem which is likely to get worse unless severe measures are taken.

In conclusion, initial vaccination with MLV vaccine (ERA strain) can induce immunological memory against rabies virus in bovines, however MLV vaccine booster up until the 16th week does not result in a rise of rabies antibody titres. In contrast, booster with the IV vaccine elevated the titres significantly. Finally, the best period for booster with IV vaccine was the 4th and 8th weeks after initial vaccination.

\section{ACKNOWLEGMENTS}

To Dr Expedito Coelho, Dr Márcio José de Figueiredo and Dr Phyllis Catharina Romijn for helpful contributions. To Dr Susan Westmoreland for reviewing the manuscript.

\section{REFERENCES}

Abbas AK, Lichtman AH, Pober JS 1995. Imunologia Celular e Molecular, Revinter, Rio de Janeiro, $440 \mathrm{pp}$.

Albas A, Alberti ALL, Minardi PLF, Pardo PE, Alberti H 1992. Avaliação do teste de contraimunoeletroforese para a detecção de anticorpos antirábicos em soros bovinos, Seminário Nacional da Raiva, São Paulo, p. 4.

Atanasiu P 1976. Titulación y prueba de potencia del soro y la immunoglobulina antirrabicos. In MM Kaplan \& H Koprowski (eds), La Rabia. Tecnicas de Laboratorio, Organización Mundial de la Salud, Genebra, p. 332-336.

Atanasiu P, Fuenzalida E, Acha P, Szyfres B 1968. Inmunidad antirrabica en bovinos vacunados. Bol Of Sanit Panam 64: 431-440.

Atanasiu P, Fuenzalida E, Acha P, Szyfres B 1976. Inmunidad antirrabica en bovinos vacunados. Rev Inst Nac Hig 9: 51-67.

Baer GM 1991. The Natural History of Rabies, 2nd ed., CRC, Boca Raton, Fl, 603 pp.

Ciuchini F, Irsara A, Pestalozza S, Trani L, Antonucci G 1981. Risposta immunitaria in bovini vaccinati contro la rabia com virus attenuato ceppo ERA. Riv
Zoo Vet 9: 176-184.

Diaz AM, Myers DM 1980. Determination of serum neutralization antibodies to rabies virus by a modified counterimmunoelectrophoresis test. J Clin Microb 12: 175-179.

Diaz AM, Myers DM 1981. Comparison between a modified counterimmunoelectrophoresis test and indirect fluorescent antibody test for detection of antibodies to rabies virus in human sera. J Clin Microb 14: 446-448.

Diaz AM, Myers DM 1984. Evaluation of hyperimmune rabies sera by the counterimmunoelectrophoresis test. J Biol Stand 12: 61-65.

Fenner F 1993. Veterinary Virology, 2nd ed., Acad Press, San Diego, 666 pp.

Gambeta WR, Chamelet EL, Souza LTM, Azevedo MP 1979. Instituto Pasteur de São Paulo: 75 Anos de Atividade, Instituto Pasteur, São Paulo, 37 pp.

Greenhall AM 1988. Feeding behavior. In AM Greenhall, Natural History of Vampire Bats, CRC Press, Boca Raton, FL, p. 111-131.

Habel K 1976. Pruebas de inocuidad y potencia de las vacunas. In M Kaplan \& H Koprowsky (eds), La Rabia. Tecnicas de Laboratorio, Organizacion Mundial de la Salud, Genebra, p. 311.

Ito FH 1988. Interferência dos Anticorpos Circulantes Previamente Desenvolvidos sobre a Resposta Imunitária em Bovinos Inoculados Subcutaneamente com Vacina Anti-rábica Inativada, MSC Thesis, Universidade de São Paulo, São Paulo, 34 pp.

Meslin FX, Fishbein DB, Matter HC 1994. Rationale and prospects for rabies elimination in developing countries. Cur Top Microbiol Immunol 187: 1-26.

Montaño JA, Hayashi Y, Martins DM, Rocha A, Masahiko O 1983. Raiva bovina em animais vacinados. Estado imunitário do rebanho. Arq Biol Tecnol 26: 373-382.

Moura WC 1993. Avaliação da Resposta Anti-rábica pela Técnica de Contraimunoeletroforese em Pessoas Vacinadas, MSC Thesis, Universidade Federal Rural do Rio de Janeiro, Itaguai, 82 pp.

Oliveira AN, Romijn PC, Andrade MCR, Moura WC, Silva MV 1994. The bovine rabies in the State of Rio de Janeiro since 1984 to 1993 . Encontro Nacional de Virologia, Sociedade Brasileira de Virologia, São Lourenço, p. 44.

Schneider MC 1990. Estudo de Avaliação de Área de Risco para Raiva no Brasil, MSC Thesis, Fundação Oswaldo Cruz, Rio de Janeiro, 203 pp.

Tadei VA, Gonçalves, CA, Pedro WG, Tadei WJ, Kotait I, Arieta C 1991. Distribuição do Morcego Vampiro Desmodus rotundus (Chiroptera, Phyllostomidae) no Estado de São Paulo e a Raiva dos Animais Domésticos, Coordenadoria de Assitência Técnica Integral, Campinas, 107 pp.

Tizard I 1985. Introdução à Imunologia Veterinária, 2nd ed., Rocca, São Paulo, 321 pp.

Tollis M 1989. Protective measures against rabies by vaccination of domestic animals. Rev Sci Tech Off Int Epiz 8: 913-914.

Turner GS 1985. Immune response after rabies vaccination: basics aspects. Ann Inst Pasteur/Virol 136: 453460 . 